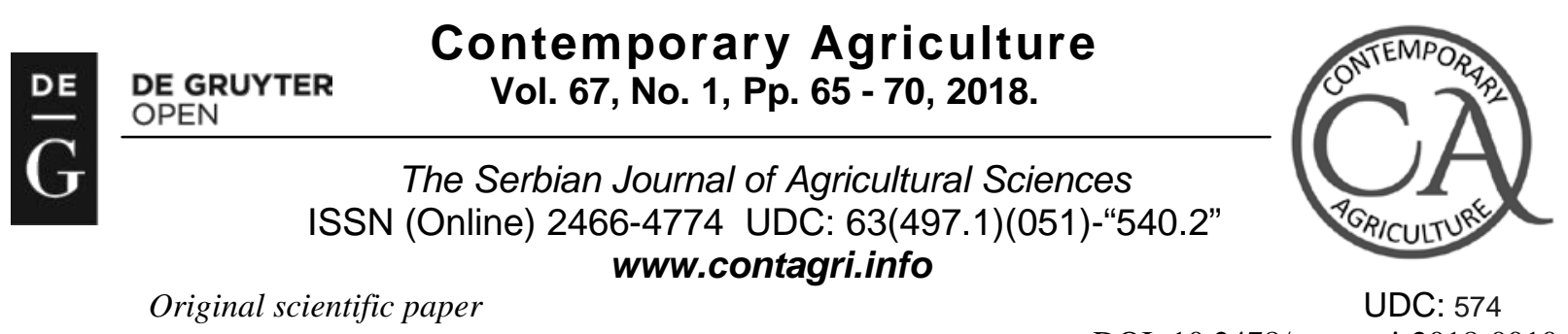

DOI: $10.2478 /$ contagri-2018-0010

\title{
MEASURING BIODIVERSITY IN FOREST COMMUNITIES - A ROLE OF BIODIVERSITY INDICES
}

\author{
Milena LAKIĆEVIĆ, Bojan SRĐEVIĆ
}

\begin{abstract}
Summary: Biodiversity refers to genetic, species and ecosystems varieties within an area. Two main characteristics that should be investigated when considering biodiversity are richness and evenness. Richness is related to the number of different species in the analyzed area, while evenness corresponds to the homogeneity of the abundance of species. For quantifying these features, many indices have been defined, and this paper offers an overview of the most commonly used biodiversity indices, such as Shannon, Simpson, Margalef and Berger-Parker. The paper explains the process of calculating these indices on the case study example of four forest communities and discusses the results obtained. The Jaccard index analysis is used to discover a similarity between the analyzed forest communities. Results from this part of the research are visualized by creating appropriate dendrograms for making the interpretation easier. Calculating and analyzing these indices is useful not only for forest ecosystems, but for the other types of ecosystems as well, including agro-ecosystems. Biodiversity indices can be obtained in thespecialized software, for instance in EstimateS (Statistical Estimation of Species Richness and Shared Species from Samples), or by programming in the statistical package $R$, as it was done in this research.
\end{abstract}

Key words: biodiversity, indices, forest communities

\section{INTRODUCTION}

Biodiversity and biodiversity preservation are among the central issues in forestry and the related science disciplines (Gross, 2016). Biodiversity refers to the variety of life forms on Earth, and is consisted of three levels: genetic, species and ecosystem diversity (Swingland, 2001). Usually, the term biodiversity is used as an equivalent for the species diversity, depicting the assembly of plant, fungi and animal species within an area (Vujić, 2008). In forest communities, having a rich species composition is prevention from having severe entomological and phytopathological attacks (Freer-Smith and Webber, 2015), as these organisms are commonly associated with specific species as their hosts. In addition, diversity of plant species composition will ensure the habitat for a broader range of animals, especially bird species (Zhao et al., 2017). Accordingly, literature sources suggest that,ideally, forest areas should have the maximum of: $10 \%$ individuals belonging to the same species, $20 \%$ belonging to the same genus and 30\% belonging to the same family (Sæbøet al., 2005).

Biodiversity includes two important features: richness and evenness(Stirling and Wilsey, 2001).Richness is related to the number of different species present in the analyzed area, while evenness discovers homogeneity (and heterogeneity) of the abundance of these species (Swingland, 2001). Therefore, for the biodiversity analysis three main input data are needed: total number of species, total number of individuals and a proportion of individuals of each species in the analyzed community. If we compare two stands, each having the equal number of different species and individuals,it is clear that their distribution will matter in terms of biodiversity significance, and that this is why the proportion is included as one of the basic inputs.Having these input values enables calculating diverse indices, and in this paper, we will focus on: Shannon, Simpson,Margalefand Berger-Parkerindices.In order to discover a degree of similarity between forest stands, an additional index has been included and that is the Jaccard index.The paper provides an overview and analysis of the most commonly used biodiversity indicators and it is backed up with a case study example of four forest stands. The same analysis can be repeated when having other

\footnotetext{
${ }^{1}$ Milena Lakićević, PhD, Assistant Proffesor, BojanSrđević, PhD, Professor Emeritus, University of Novi Sad, Faculty of Agriculture, Trg D. Obradovića 8, 21000 Novi Sad, Serbia.

• Corresponding author: Milena Lakićević, e-mail: milenal@polj.uns.ac.rs, Tel.: +381214853262
} 
communities to deal with;it can also be applied when analyzing agro-ecosystems. The purpose of this research paper is to present the methodology forcalculating biodiversity indices and analyzing similarities between forest communities; andthis type of data and analysis are extremely important to characterize ecosystems (Ioannou et al., 2014).

\section{MATERIAL AND METHOD}

Forest stands that are analyzed in the paper are briefly described in Table 1 . There are nine different species registered across all of them.

Table 1.Composition offorest community speciesin the analyzed forest stands

\begin{tabular}{|c|c|c|c|c|}
\hline Forest community species & Forest stand 1 & Forest stand 2 & Forest stand 3 & Forest stand 4 \\
\hline Species 1 & 12 & 9 & 0 & 12 \\
\hline Species 2 & 0 & 10 & 0 & 2 \\
\hline Species 3 & 5 & 0 & 0 & 7 \\
\hline Species 4 & 17 & 4 & 10 & 0 \\
\hline Species 5 & 10 & 9 & 15 & 0 \\
\hline Species 6 & 0 & 5 & 8 & 5 \\
\hline Species 7 & 9 & 0 & 14 & 0 \\
\hline Species 8 & 0 & 6 & & \\
\hline Species 9 & 0 & 5 & & \\
\hline
\end{tabular}

Biodiversity indices have been calculated for the presented forest stands. Each of the indices used is described in the following text.

Shannon index $(H)$ (Shannon,1948)describes both richness and evenness and is calculated as:

$$
H=-\sum_{i=1}^{s} p_{i} \ln \left(p_{i}\right)
$$

where $p_{i}$ is a proportion of individuals of species $i$ in the total number of individuals presented in the area. The Shannon index usually takes values in between 1.5 and 3.5(Magurran, 2004). If an area has a value of Shannon index equal or higher than 4, it is considered as extraordinary from the biodiversity perspective.

Simpson index $(D)$ (Simpson,1949)is a measure for evenness and is calculated as:

$$
D=1-\left(\frac{1}{\sum_{i=1}^{s} p_{i}^{2}}\right)
$$

where $S$ represents the total number of species. The values of Simpson index vary in between 0 and 1 and that makes the analysis more intuitive, the higher values correspond to higher biodiversity. It should be noted that Simpson index can be presented in two other, similar forms, but the formula presented is the most commonly used.

Margalef index $(R)$ (Margalef,1958) measures the evenness, but it is highly sensitive to the sample size (Gamito, 2010). It is calculated following the rule: 


$$
R=\frac{5-1}{\log N}
$$

where $N$ represents the total number of individuals. This parameter does not have threshold values, and its higher values prove higher biodiversity.

Berger-Parker index $(d)$ (Berger-Parker,1970)measures the dominance of the most abundant species, and is therefore primarily related to evenness. It is calculated as:

$$
a=\frac{N_{\max }}{N}
$$

where $N_{\max }$ is the number of individuals of the most abundant species. The values vary in between 0 and 1 , where values closer to 0 correspond to higher diversity and the value of 1 reveals monoculture.

Jaccard index $(J)$ (Jaccard,1901)is a measure of similarity between two sets of elements, and it is applied for diverse problems including the ones in environmental studies. This index is calculated as:

$$
I(X, Y)=\frac{X \cap Y}{X \cup Y}
$$

where $X$ and $Y$ are any forest stands analyzed. The intersection of two communities represents the number of species they have in common, while union represents the sum of: the number of common species, the number of species present only in the stand $X$ and the number of species present exclusively in the stand $Y$. Along with this value, $1-J$ is often calculated as a supporting index, and it is called Jaccard distance.

Analyzing biodiversity indicators can be performed in some of the specialized software, e.g. EstimateS (Statistical Estimation of Species Richness and Shared Species from Samples) (Colwell, 2013), but in this paper the analysis was performed in the statistical package R (IhakaandGentleman, 1996) version 3.3.3.

\section{RESULTS AND DISCUSSION}

Biodiversity indices have been calculated for all analyzed forest stands and the results are presented in Table 2.

Table 2. Biodiversity indices in the analyzed forest stands

\begin{tabular}{|c|c|c|c|c|}
\hline \multirow{2}{*}{ Forest stand } & \multicolumn{4}{|c|}{ Biodiversity indices } \\
\cline { 2 - 5 } & Shannon & Simpson & Margalef & Berger-Parker \\
& $(H)$ & $(D)$ & $(R)$ & $(d)$ \\
\hline Forest stand 1 & 1.539 & 0.773 & 1.007 & $\mathbf{0 . 3 2 1}$ \\
\hline Forest stand 2 & $\mathbf{1 . 8 9 3}$ & $\mathbf{0 . 8 4 8}$ & $\mathbf{1 . 5 4 9}$ & 0.208 \\
\hline Forest stand 3 & 1.582 & 0.789 & 0.989 & 0.263 \\
\hline Forest stand 4 & 1.675 & 0.796 & 1.365 & 0.308 \\
\hline
\end{tabular}

Description: Values written in bold represent the highest value and values written in italic represent the lowest value among the analyzed forest stands.

Interpretation of the results shows that forest stand 2 is the most valuable one from the biodiversity perspective, taking into account richness and evenness. This forest stand has the highest values of Shannon, Simpson and Margalef indices, and the lowest value of Berger-Parker index, in comparison to the rest of the forest stands included in the research. The value of Berger-Parker index shows that the most abundant species is present with $20.8 \%$ in tree species composition, and theoretically the ideal value in this case would be $11.11 \%$ (meaning that all nine species are 
equally distributed). Following that, forest stand 1 has the lowest values ofShannon and Simpson index and the most abundant species accounts for32.1\% of the forest community composition(see value of Berger-Parker index), and this is thereason for the low values of indices measuring richness and evenness.

Table 3 shows the values of Jaccard index of similarity between the analyzed forest stands. This feature is commutative and thisis the reason why only the upper triangle of the matrix is filled in.

Table 3.Jaccard index of similarity amongthe analyzed forest stands

\begin{tabular}{|c|c|c|c|}
\hline & Forest stand 1 & Forest stand 2 & Forest stand 3 \\
\hline Forest stand 2 & 0.333 & & \\
\hline Forest stand 3 & 0.433 & 0.333 & \\
\hline Forest stand 4 & 0.375 & $\mathbf{0 . 6 2 5}$ & 0.222 \\
\hline
\end{tabular}

Description: Values written in bold represent the highest value and values written in italic represent the lowest valueof similarity amongthe analyzed forest stands.

The results in the Table show that, based on the value of Jaccard index, forest stand 2 and forest stand 4 have the highest mutual similarity. This analysis is important especially when defining forest management plans; forest stands that are more similar to each other can be managed in a similar way. In addition, based on the values presented in Table 3,it is possible to cluster the forest stands accordingly and create appropriate dendrograms (Figure 1).

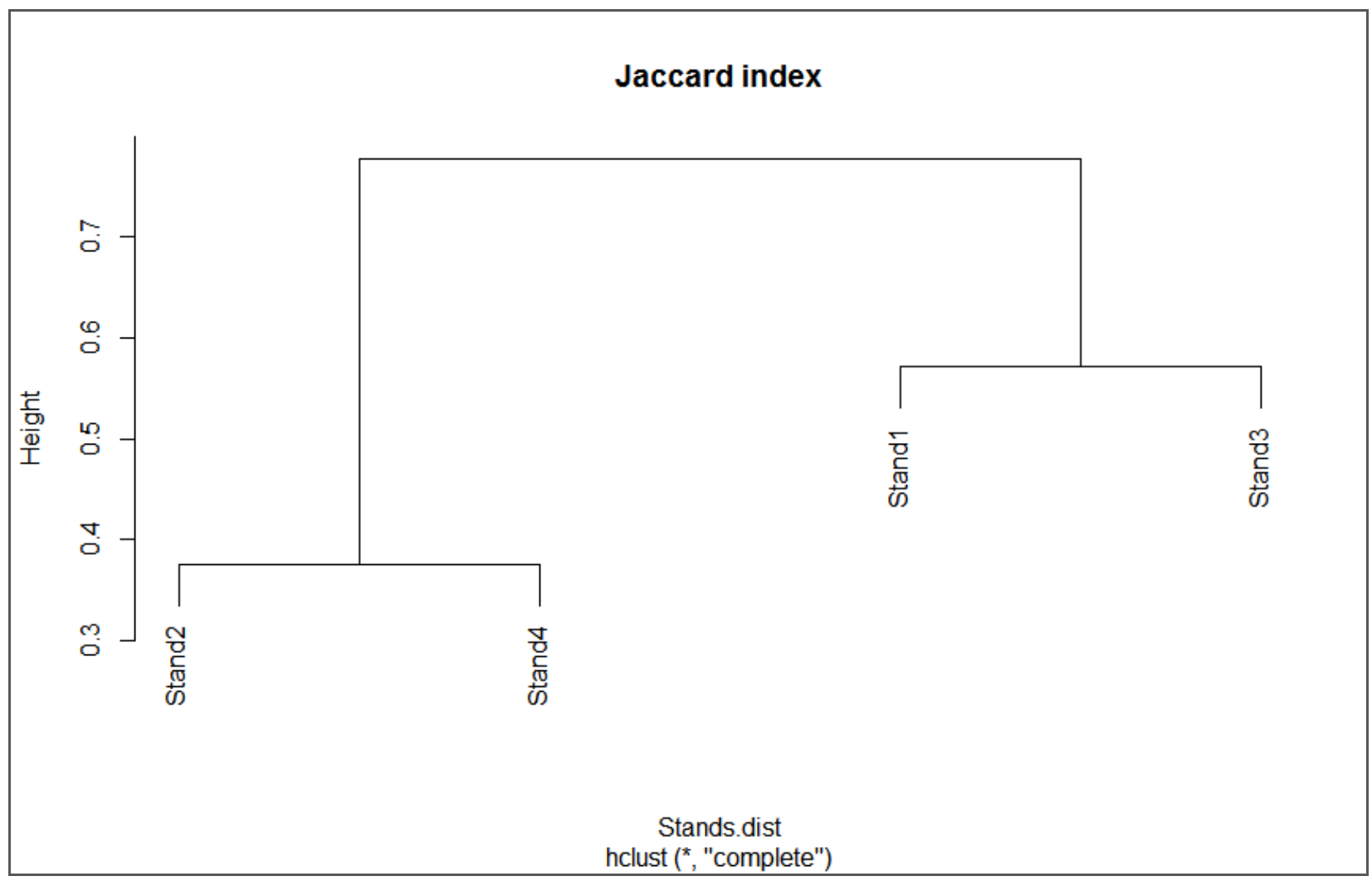

Figure 1. Clustering forest stands based on the value of Jaccard index

Figure 1 shows the clustering of forest stands and the $y$-axis (height) presents the Jaccard distance. The results in the Figure confirm that Stand 2 and Stand 4 are the most similar (the Jaccard distance is equal to 0.375) and after that 
Stand 1 and Stand 3 can be clustered (the Jaccard distance is equal to 0.576). Creating the dendrograms is supposed to make the interpretation of the results easier and it is easy to make them in the $\mathrm{R}$ package.

\section{CONCLUSION}

Measuring biodiversity is an important task in assessing and evaluating forest or agricultural communities. There are indices for quantifying biodiversity based on its two main features: richness and evenness.

This paper offers an overview of the most commonly applied biodiversity indices: Shannon, Simpson, Margalef and Berger-Parker; describes how they are calculated on a case study example and discusses the results obtained. High values of Shannon, Simpson and Margalef indices refer to high biodiversity, while high values of BergerParker index show that a community is close to monoculture and therefore less valuable in biodiversity terms.

Apart from analyzing thebiodiversity indices for each forest stand or community individually, it is also useful to make a comparison between them. Jaccard index of similarity enables this comparison, for a pair of communities, by taking into accountthe number species that are present in both communities and the number of species that are present exclusively in each of them. Knowing the degree of similarity can be especially useful when stating management options, because forest stands with a high overlap of tree species composition are expected to have similar management plans. The same or similar analysis can be applied when specifying management options for agricultural production, and the recommendation would be to test the procedurepresented in this paper for these purposes.

Future research might additionally explore the possibilities of biodiversity indices calculation on the real case study examples. These can be parks, urban forests, agro-forestry communities and so on.

\section{ACKNOWLEDGEMENT}

The authors acknowledge grants received from the Ministry of Ministry of Education, Science and Technological Development of the Republic of Serbia under contract No. 174003: Theory and application of the analytic hierarchy process (AHP) in multi-criteria decision making under conditions of risk and uncertainty (individual and group context).

\section{REFERENCES}

BERGER WH, PARKER FL: Diversity of planktonic foraminifera in deep sea sediments. Science, 168, 1345-1347, 1970.

COLWELL RK: EstimateS: Statistical Estimation of Species Richness and Shared Species from Samples. Version 9.1.0. User's guide published at http://purl.oclc.org/estimates, 2013.

FREER-SMITH PH, WEBBER JF: Tree pests and diseases: the threat to biodiversity and the delivery of ecosystem services. Biodiversity Conservation, 1-15, 2015.

GAMITO S: Caution is needed when applying Margalef diversity index. Ecological Indicators, 10(2)550-551, 2010.

GROSS M: How can we save forest biodiversity? Current Biology, 26(22)1167-1170, 2016.

IHAKA R, GENTLEMAN R: A Language for Data Analysis and Graphics. Journal of Computational and Graphical Statistics. 4(3)299-314, 1996.

IOANNOU K, EMMANOULOUDIS D, LEFAKIS P, MYRONIDIS D: Design and implementation of an environmental network for the requirements of a European funded research project. International Journal of Applied Systemic Studies, 5(4)249-261, 2014.

JACCARD P: Étude comparative de la distribution floraledansune portion des Alpes et des Jura, Bulletin de la Société Vaudoise des Sciences Naturelles,37, 547-579, 1901.

MAGURRAN AE:Measuring Biological Diversity. Blackwell Publishing, London, 2004.

MARGALEF R: Information theory in ecology. General Systems, 3, 36-71, 1958.

SÆBØ A, BORZAN Ž, DUCATILLION C, HATZISTATHIS A, LAGERSTRÖM T, SUPUKA J, GARCÍA-VALDECANTOS JL, REGO F, VAN SLYCKEN J: The Selection of Plant Materials for Street Trees, Park Trees and Urban Woodland. In: Urban Forests and Trees: A Reference Book. (C. Konijnendijk, K. Nilsson, T. Randrup, J. Schipperijn,eds.). Springer Berlin Heidelberg, Berlin, Heidelberg, pp. 257-280, 2005.

SHANNON CE: A mathematical theory of communication. The Bell System Technical Journal, 27, 623-656, 1948.

SIMPSON EH: Measurement of diversity. Nature, 163, p. 688, 1949.

STIRLING G, WILSEY B: Empirical relationships between species richness, evenness and proportional diversity. The American Naturalist,158(3)286-299, 2001.

SWINGLAND IW (2001): Biodiversity, definition of. In: Encyclopedia of Biodiversity. Volume I ( S.A Levin, ed.),Academic Press, San Diego, pp. 377-391, 2001 
VUJIĆ A: Nature protection. University of Novi Sad, Faculty of Sciences, p. 12, 2008 (In Serbian).

ZHAO Q, MASON THE, AZERIA ET, LE BLANC ML, LEMAÎTRE J, BARNIER F, BICHET O, FORTIN D: Robust predictive performance of indicator species despite different co-occurrence patterns of birds in natural and managed boreal forests. Forest Ecology and Management, 397, 108-116, 2017.

\title{
ODREĐIVANJE BIODIVERZITETA U ŠUMSKIM ZAJEDNICAMA - ULOGA INDIKATORA BIODIVERZITETA
}

\author{
Milena LAKIĆEVIĆ, Bojan SRĐEVIĆ
}

Izvod: Biodiverzitet se odnosinasveukupnostgena, vrstaiekosistema u određenompodručju. Dve glavne karakteristike biodiveriteta su: bogatsvo i ujednačenost. Bogatstvo se odnosi na broj različitih vrsta, a ujednačenost na njihovu raspodelu. Ove karakteristike se mogu kvantifikovati korišćenjem većeg broja indikatora, a u ovom radu su prikazani indikatori koji se najčešće koriste: Šenonov, Simsonov, Margalefov i Berger-Parkerov. Rad prikazuje postupak proračuna navedenih indikatora na primeru studije slučaja četiri šumske zajednice i analizira dobijene rezultate. Dodatno, primenjen je i Džakardov indeks u cilju utvrđivanja sličnosti između analiziranih šumskih zajednica. Rezultati ovog dela istraživanja su prikazani pomoću odgovarajućeg dendrograma, kako bi se pojednostavilo tumačenje. Određivanje i analiza navedenih indikatora je korisna ne samo za šumske, već i za druge ekosisteme, uključujući agro-ekosisteme. Proračun indikatora biodiverziteta moguće je obaviti u nekom od specijalizovanih softvera, npr. EstimateS ili programiranjem u statističkom paketu R, kao što je urađeno u ovom istraživanju.

Ključne reči: biodiverzitet, indikatori, šumske zajednice

Received / Primljen: 09.06.2017. Accepted / Prihvaćen: 18.12.2017. 